\title{
Toplam Faktör Verimliliğinin Belirleyicileri Üzerine Ampirik Bir İnceleme: Seçilmiş OECD Ülkeleri Örneği
}

\author{
Mustafa Gömleksiz ${ }^{1}$ \\ Ahmet Şahbaz ${ }^{2}$ \\ Birol Mercan ${ }^{3}$
}

Toplam Faktör Verimliliğinin Belirleyicileri Üzerine Ampirik Bir İnceleme: Seçilmiş OECD Ülkeleri Örneği

Öz

Günümüzde, ülkelerarası gelir ve ekonomik büyüme farklılıklarının önemli bir kısmı verimlilikte ortaya çıkan farklılıklardan kaynaklanmaktadır. İktisadi büyüme odaklı politikalar çerçevesinde verimliliği belirleyen unsurların incelenmesi önem arz etmektedir. Bu çalışmanın amacı, toplam faktör verimliliğinin potansiyel belirleyicilerini analiz etmektir. Bu kapsamda beşeri sermaye, Ar-Ge, ticari dışa açıklık ve ileri teknolojili ürün ithalatının toplam faktör verimliliği üzerindeki etkileri seçilmiş 12 OECD ülkesine ait 1993-2014 yılları arası dönemde ekonometrik olarak incelenmektedir. Analiz sonucu elde edilen bulgular Ar-Ge, ticari dışa açıklık ve ileri teknoloji ürün ithalatının verimlilik artışlarında önemli birer belirleyici olduğunu gösterirken, beşeri sermayeye ilişkin anlamlı bir bulguya rastlanmamıştır.

Anahtar Kelimeler: Toplam Faktör Verimliliği, Ar-Ge, Ticari Dışa Açıklık, İleri Teknoloji Ürün İthalatı, Beşeri Sermaye, Panel Eşbütünleşme
An Analysis on the Determinants of Total Factor Productivity: The Case of Selected OECD Countries

\section{Abstract}

In recent years, it can be argued that a significant part of the cross-country differences in income and economic growth mostly arise from the differences in productivity levels. Thus, the examination of the sources of productivity is an important issue in the context of growth-oriented policies. This study aims to investigate potential determinants of total factor productivity. In this respect, the effects of human capital, R\&D, trade openness and high technology product imports on total factor productivity are analyzed across the selected 12 OECD countries for the 1993-2014 period. The findings of the analysis show that R\&D, trade openness and high-technology imports are important determinants of productivity growth. Also, the results indicate no significant evidence for human capital.

Keywords: Total Factor Productivity, R\&D, Trade Openness, High-Tech Imports, Human Capital, Panel Cointegration

\section{Giriş}

İktisadi girdilerin daha üretken bir şekilde kullanımını ifade eden verimlilik kavramı, uzunca bir süredir, gelir ve refah düzeyinin iyileştirilmesi çabalarında önemli bir kaynak olarak kabul görmektedir. Bu bağlamda, ülkelerarası gelir ve ekonomik büyüme farklılıklarının önemli bir kısmının verimlilikte ortaya çıkan farklılıklardan kaynaklandığı söylenebilir (Hall ve Jones, 1999: 83; Dünya Bankası, 2000: 1). Verimlilik kavramı iktisat alanında çok sayıda teorik ve ampirik çalışmaya konu olmuştur. Bu kapsamda ilk olarak Solow (1956) tarafından büyüme modeline teknolojik değişimin bir ölçütü olarak dâhil edilen verimlilik kavramı, modelde dışsal bir süreç olarak ele alınmıştır. Bunu takiben Solow (1957), çıktı artışının faktör birikimindeki ve verimlilikteki artışlara bağlı olduğunu ileri sürmüştür. Bu yaklaşıma göre emek, sermaye veya doğal kaynakları içerisine alan sabit bir faktör girdi bileşiminin kullanıldığı üretimdeki artışlar, teknolojik ilerleme ya da başka bir deyişle verimlilikteki iyileşmeler sonucu ortaya çıkmaktadır. Literatürde "Solow artığı" olarak da bilinen verimlilik kavramına iktisadi büyüme kapsamında atfedilen bu öneme rağmen verimliliğin kaynaklarının tam olarak açıklanmaması, kavramın o dönemde kapalı bir

\footnotetext{
${ }^{1}$ Arş. Gör., Necmettin Erbakan Üniversitesi SBBF, íktisat Bölümü. mgomleksiz@konya.edu.tr

${ }^{2}$ Doç. Dr., Necmettin Erbakan Üniversitesi SBBF, iktisat Bölümü. asahbaz@konya.edu.tr

${ }^{3}$ Doç. Dr., Necmettin Erbakan Üniversitesi SBBF, iktisat Bölümü, bmercan@konya.edu.tr
} 
kutu olarak kalmasına neden olmuştur. Buna karşılık, toplam faktör verimliliği ya da çoklu faktör verimliliği olarak adlandırılan bu "artık" terime yakın zamanda ortaya çıkmış çalışmalarda geniş yer verilmeye başlandığı görülmektedir.

Toplam faktör verimliliğini belirleyen unsurların analizi, uzun dönem iktisadi büyüme ve yaşam standartlarının yükseltilmesine yönelik çabalarda önemli bir yol haritası sunmaktadır (OECD, 2001: 12). Literatürde, verimlilik analizine yönelik çalışmaların Abramovitz (1956) ile başladığı söylenebilir. Bu kapsamda Abramovitz (1956), 1869-1953 yılları arası dönemde ABD'deki verimlilik artışlarının kaynaklarını incelediği çalışmasıyla, elde ettiği sonuçlar her ne kadar gerçekçilikten uzak olsa $\mathrm{da}^{4}$, konuyla ilgili literatüre önemli bir ivme kazandırmıştır. Aynı dönemde Solow (1957) tarafından büyüme muhasebesine dâhil edilen "artık" terime ilk eleştiri Jorgenson ve Griliches (1967) tarafından getirilmiştir. Jorgenson ve Griliches (1967: 249), teknolojik ilerlemenin ölçülebilir girdilerle somutlaştırıldığı bir büyüme muhasebesi çerçevesinde, söz konusu artıkların tamamen ortadan kaldırılabileceğini ve çıktı artışının tamamının fiziksel girdilerdeki büyümeyle açıklanabileceğini savunmuştur. Bu görüşe karşın Denison (1969: 1), savaş sonrası dönemde gerçekleşen büyümenin önemli bir kısmının fiziksel girdilerden ziyade verimlilikteki artışlardan kaynaklandığını göstermiştir. Denison (1969)'a göre teknik, yönetsel ve örgütsel bilgideki gelişmeler, belirli bir miktarda girdi ile daha fazla çıktı elde edilmesini sağlamakta, dolayısıyla girdilerin niteliğindeki değişim, somutlaştırılmış teknolojik ilerleme ile sonuçlanan bu gelişmelerden kaynaklanmaktadır (Denison, 1969: 25).

Verimliliğin ölçülmesi, ülkelerin geçmiş ve potansiyel ekonomik performanslarının değerlendirilmesi hususunda önem arz etmektedir (Dünya Bankası, 2000). Verimlilik ölçümü kapsamında Stigler (1947), işçi başına çıktıda meydana gelen değişimlerin, çıktı değişiminde üretici tüm birimleri dikkate alan verimlilik değişimleri ile karıştırılmaması gerektiğini vurgulamıştır. Stigler'e göre, üretim sürecinde çıktılarda meydana gelen bir artış hem emek hem de işbirlikçi bazı faktörlerden kaynaklanabilmekte ve bu artışın girdilerden yalnızca birine atfedilmesi verimliliğin ölçümünde hatalı sonuçlar ortaya çıkarmaktadır ${ }^{5}$ (Stigler, 1947: 43). Ayrıca tek bir girdiye dayanan ölçümler, bu girdiyi kullanan endüstriler arasındaki kullanım yoğunluğu farklılıklarından da etkilenebilmektedir. Bu kapsamda, brüt iktisadi çıktıların üretim sürecine konu olan tüm girdilere oranını ifade eden toplam faktör verimliliğinin, genellikle emek ve sermaye gibi belirli bir faktör girdisini dikkate alan kısmi faktör verimliliğine kıyasla daha kapsamlı bir ölçüt olduğu söylenebilir (Tocco, 2015: 13). Dolayısıyla toplam faktör verimliliği bir yandan emek, sermaye ve teknolojinin büyümeye yaptıkları doğrudan katkıları ölçmeye yardımcı olurken, diğer yandan ekonomik büyümenin geçmişteki seyrini gözden geçirme ve gelecekteki ekonomik büyüme potansiyelini değerlendirme hususunda önemli bir araç sunmaktadır (OECD, 2001: 20).

Toplam faktör verimliliği kapsamında, Easterly ve Levine (2001) tarafından dünya genelindeki uzun dönem ekonomik büyüme ve büyümeyle ilgili politikalara ilişkin yapılan bazı tespitler şunlardır (Easterly ve Levine, 2001: 179-180):

i. $\quad$ Faktör birikimi tek başına, kişi başına gayri safi yurtiçi hâsıla (GSYH) büyüme hızında ülkelerarası ortaya çıkan kayda değer farklııkları açıklamamaktadır. Dolayısıyla, uzun

\footnotetext{
${ }^{4}$ Abramovitz'in (1956: 11) çalışmasında, verimlilik artışının ana kaynaklarının halen belirsiz olduğu sonucuna varmıştır. Abramovitz'e göre bu sonuç, ekonomik büyümenin nedenleri hakkındaki bilgisizliğimizin bir ölçütü olmakla birlikte, bu nedenlerin araştırılmasında dikkatimizi nereye yoğunlaştırmamız gerektiğine de işaret etmektedir.

${ }^{5}$ Stigler (1947: 5) bu görüş çerçevesinde, toplam maliyetler içerisinde işçilik maliyetlerinin nispeten düşük paya sahip olduğu endüstrilerdeki verimliliğin ölçümünde, işçi başına çıktıdaki değişimlerin güvenilmeyen bir kılavuz olacağını belirtmiştir.
} 
dönem ekonomik büyümenin sağlanmasına yönelik atılan adımlarda toplam faktör verimliliğinin belirleyicilerinin incelenmesi ve faktör verimliliğini artırıcı politikalar ve kurumların geliştirilmesine öncelik verilmesi gerekmektedir.

ii. Faktör temelli ve azalan getirilere tabi modeller, teknolojik ilerleme odaklı ve artan getiriler sergileyen modellere kıyasla, ülkelerarası artan gelir farklııklarını açıklamada yetersiz kalmaktadır.

iii. İktisadi büyüme, sermaye birikimindeki büyümeye kıyasla sürekli değildir. Bir başka deyişle, faktör birikimindeki değişimler büyümedeki trendi izlememektedir.

iv. Toplam faktör verimliliği odaklı politikalar, sermayenin ve emeğin üretkenliğini artırma ya da içsel teknolojik değişimi gerçekleştirme yoluyla verimlilik artışını sağlayabilmekte ve bu suretle uzun dönem ekonomik büyümeyi hızlandırabilmektedir.

Geçtiğimiz yirmi yıllık süreçte, toplam faktör verimliliği kapsamında OECD ülkeleri arasında da önemli farklııkların ortaya çıktığı görülmektedir. Bu süreçte özellikle, faktör verimliliğinin oldukça düşük ve hatta negatif seviyeleri gördügü İtalya ve İspanya, verimlilikte önde gelen Kore ve İrlanda gibi ülkelerin oldukça gerisinde kalmışlardır. Bunun yanı sıra, 2001-2007 yılları arası dönemle karşılaştırıldığında, 2008 küresel krizi sonrası OECD ülkelerinin neredeyse hepsinde görülen toplam faktör verimliliği artış hızındaki yavaşlama özellikle Finlandiya, İsveç ve İngiltere'de önemli bir seviyede gerçekleşmiştir. Ayrıca, toplam faktör verimliliği artış hızındaki yavaşlamanın ülkelerarası emek verimliliğindeki artışları da olumsuz etkilediği görülmektedir. Bu bağlamda, OECD ülkelerindeki kriz sonrası verimlilik değişimlerinin bir yandan büyüme hızında büyük düşüşlere, diğer yandan emek verimliliğinde anlamsız ya da negatif etkilere yol açan bir konjonktürde seyrettiği ifade edilebilir (OECD, 2015: 30). Dolayısıyla ortaya çıkan bu tablo, verimliliği etkileyen faktörlerin söz konusu ülkeler kapsamında incelenmeye değer bir konu olduğunu göstermektedir.

Bu çalışmada, literatürde ortaya çıkan çeşitli yaklaşımlar dikkate alınarak, toplam faktör verimliliğine etki edebilecek değişkenlerin analiz edilmesi amaçlanmaktadır. Bu amaçla, beşeri sermaye, Ar-Ge, ticari dışa açıklık ve ileri teknolojili ürün ithalatının toplam faktör verimliliği üzerindeki etkileri seçilmiş 12 OECD ülkesi kapsamında ekonometrik olarak incelenmektedir. Çalışmanın analiz kısmını oluşturan 1993-2014 yılları arası döneme ait panel veri seti, başta OECD olmak üzere çeşitli veri tabanlarından elde edilmiştir. Çalışmanın bir sonraki bölümünde, toplam faktör verimliliğinin belirleyicileri kapsamında ortaya çıkmış çeşitli teorik yaklaşımlara yer verilmektedir. Üçüncü bölümde, konuyla ilgili ampirik literatürün bir özeti sunulmaktadır. Dördüncü ve beşinci bölümde sırasıyla çalışmanın analiz kısmında kullanılan veri seti, yöntem ve analiz sonucu elde edilen bulgular yer almaktadır. Son bölümde ise çalışmada ulaşılan çeşitli sonuçlar değerlendirilmektedir.

\section{Toplam Faktör Verimliliğinin Belirleyicileri}

Literatürde, verimlilik değişimlerinde rol oynayan farklı potansiyel unsurların incelendiği çok sayıda mevcuttur. Bu çalışmaların bir kısmı toplam faktör verimliliği kapsamında ortaya çıkan ülkelerarası farklııılara odaklanırken (Coe ve Helpman, 1995; Domazlicky ve Weber, 1998; Garces-Ozanne, 2001; Ascari ve Di Cosmo, 2004; Khan, 2006; Nachega ve Fontaine,2006; Isaksson, 2007; Jajri, 2007; Loko ve Diouf, 2009; Khan vd., 2010; Arazmuradov vd., 2013; Gehringer vd., 2013; Raggl, 2015; Akinlo ve Adejumo, 2016; Filip, 2016), diğer çalışmaların endüstri veya firma bazında verimliliğin kaynaklarını incelediği (Biatour vd., 2011; Tocco, 2015) söylenebilir. Söz konusu çalışmalarda, verimliliğe etki eden faktörlerin analizine ilişkin olarak beşeri sermaye, ticari 
dışa açıklık, yerli ve yabancı yatırımlar, araştırma ve geliştirme (Ar-Ge), enflasyon ve çeşitli kurumsal faktörlerin ele alındığı görülmektedir.

OECD (2001) beşeri sermayeyi kişisel, sosyal ve ekonomik refahın yaratılmasını kolaylaştıran bilgi, beceri, yetkinlik ve nitelikler olarak tanımlamaktadır. Beşeri sermayeye konu olan bu unsurlar doğuştan (ability) olabilmekte veya öğrenme (learning by doing, skill) yoluyla kazanılıp geliştirilebilmektedir. Verimlilikle ilgili ortaya çıkan teorik literatürde, beşeri sermayenin yeni teknolojilerin edinilmesi ve uygulanmasını kolaylaştırma veya teknolojik inovasyonların ortaya çıkışını hızlandırma yoluyla verimlilik artışlarına katkı sağladığı öne sürülmektedir (Romer, 1990: 79; Benhabib ve Spiegel, 1994: 144; Aghion ve Howitt, 1998: 328). Yabancı teknolojinin edinimi sadece eğitimin niceliğine değil, aynı zamanda niteliğine de bağlı olduğundan, yetersiz beşeri sermaye yatırımların verimlilik üzerindeki etkisi zayıf olacaktır (Aghion ve Howitt, 2009). Bunun yanı sıra literatürde, bilginin somut bir hâli olarak beşeri sermaye stokunun teknolojik ilerlemede kritik bir rol oynadığı ve dolayısıyla ülkelerarası büyüme ve verimlilik farklılıklarının ortaya çıkışında önemli bir belirleyici olduğuna yer verilmektedir (Arrow, 1962: 155; Nelson ve Phelps, 1966: 72). Beşeri sermayenin doğrudan ölçümü tartışmalı bir konu olmakla birlikte ${ }^{6}$, yapılan çalışmalarda genellikle eğitime ilişkin göstergelerin kullanıldığı görülmektedir. Örneğin, OECD (2004) tarafından yapılan bir çalışma, eğitimde ortalama geçirilen süredeki bir yıllık artışın toplam verimliliği \% 5 artırdığını gösterirken, Canton (2007) işgücünün ortalama eğitim düzeyindeki bir yıllık bir artışın emek verimliliğini kısa dönemde \% 7-10 ve uzun dönemde ise \% $11-15$ oranında artırdığı sonucuna ulaşmıştır.

Toplam faktör verimliliği kapsamında değinilebilecek diğer bir faktör Ar-Ge faaliyetleridir. OECD (1993) tarafından yayınlanan Frascati Kılavuzu Ar-Ge'yi “bilgi stokunu artırmak ve bu bilgi stokunun yeni uygulamalar tasarlamak için kullanılmasını sağlamak için sistematik bir temelde üstlenilen yaratıcı çalışmalar" olarak tanımlamıştır (OECD, 1993: 29). Ar-Ge faaliyetleri teknolojik ilerleme süreçlerinin önemli bir kaynağı olarak görülmektedir. Bu süreçlerde mevcut bilgi stoku, uzmanlık, yaratıcılık ve çeşitli destekleyici hizmetler olarak tanımlanabilecek Ar-Ge girdileri, yeni bilgi stoku ve teknoloji düzeyinin artırılmasına katkı sağlamaktadır. Ar-Ge aynı zamanda bilgiyi tanımlama, adapte etme ve uygulamaya yönelik kapasitelerin geliştirilmesinde de önemli bir işlev görmektedir (Parham, 2007: 3). Ar-Ge faaliyetlerinin verimlilik üzerindeki etkisi genel olarak bilgi yaratımı ve inovasyon yoluyla gerçekleşmektedir. Bu kapsamda özel sektör tarafından gerçekleştirilen Ar-Ge faaliyetleri yeni mal ve hizmetler, daha yüksek kalitede ürünler veya yeni üretim süreçleriyle sonuçlanabilmektedir. Söz konusu çıktılar aynı zamanda firma ölçeği ve makro düzeyde verimlilik artışlarının da kaynaklarıdır. Bunun yanı sıra, kamu sektörü ve üniversiteler tarafından gerçekleştirilen araştırma faaliyetleri bilimsel bilgi tabanı üzerinde doğrudan etkili olmakta ve toplumsal bilgi stokunu artırmaktadırlar (Guellec ve Van Pottelsberghe, 2001: 105). Dolayısıyla, başta özel sektör tarafında Ar-Ge'ye yapılan yatırımların verimlilik üzerinde anlamlı bir pozitif etki yarattığı ve orta-uzun vadede diğer verimlilik odaklı yatırımlarla benzer getiriler sağladığı söylenebilir (The Congress of the United States, 2005: 1).

Literatürde ticari liberilizasyonun verimlilik artışına katkı sağladığına yönelik bulgulara da sıklıkla rastlanmaktadır (Edwards, 1998; Miller ve Upadhyay 2000; Isaksson, 2007; Jajri, 2007). Dış pazarlara erişimin artması, artan rekabetçi baskılar, teknolojik gelişmelere erişimin kolay-

\footnotetext{
${ }^{6}$ Konuyla ilgili tartışmalar özellikle, eğitimde geçirilen sürenin eğitimin niteliğindeki farklılıkları yansıtmadığı görüşü çerçevesinde ortaya çıkmaktadır. Örneğin, Barro ve Lee (1993), uluslararası karşılaştırılabilir bir ölçüt olarak eğitimde geçirilen sürenin ülkelerarası niteliksel farklılıkları hesaba katmadığını vurgulamaktadırlar.
} 
laşması ve taşma (spillover) etkileri aracılığıyla firma verimliliğini desteklemektedir. Bu bağlamda ticari dışa açıklık, başarılı yenilikçi firmalara yönelik pazar hacmini, üretim ölçeğini ve dışsallıklar yoluyla öğrenme faaliyetlerini artırabilmektedir. Dolayısıyla dışa açıklık, yerli firmaların daha ucuz ve daha iyi teknolojiye, daha kaliteli girdilere ve yurt dışındaki yönetsel becerilere erişimine imkân vermektedir. Ayrıca, ticari dışa açıklığın gelişmiş ülkelerden daha az gelişmiş ülkelere ve sektörlere doğru bilgi yayılmalarını da teşvik ettiği söylenebilir. Teknolojik yakınsama hızına doğrudan etki eden bu yayılma etkileri verimlilikteki artışları da desteklemektedir (Aghion ve Howitt, 2009: 353-373). Nitekim OECD ülkeleri genelinde yakın zamanda yapılan bir çalışma, ihracattaki artışların neticesi olarak dışa açıklığın görece fazla olduğu ülkelerde kişi başına düşen GSYH'nin daha yüksek olduğunu ve bu ülkelerin aynı zamanda emek verimliliklerini de artırdıklarını göstermektedir (OECD, 2015: 50).

Verimlilik artışları ile sonuçlanan bilgi yığıımalarının ortaya çıkışında uluslararası teknoloji transferinin önemli bir payı vardır. Coe ve Helpman (1995), ulusal ve uluslararası boyutta bilgi birikiminin verimliliği artırıcı etkilerinden bahsetmektedir. Bu görüşe göre uluslararası teknoloji transferi, teknolojik ürün ithalatı ve doğrudan yabancı yatırımlar olmak üzere iki farklı kanalla gerçekleşebilmektedir. Blalock ve Veloso (2005), literatürde verimliliğe dayalı mevcut modellerin ithalat yoluyla öğrenmeye ilişkin iki temel mekanizmaya dayandığından söz etmektedirler. Bunlardan ilki, ileri teknoloji ara girdilerin ithalat yoluyla yerel üretim zincirlerine dâhil edilmesiyle gerçekleşen öğrenme mekanizmasıdır. Bu süreçte ithalat, yabancı kaynaklı teknolojik kabiliyetler ve Ar-Ge'nin somutlaşmış hali olan ürünler ve ara girdiler yoluyla firmaya iletimini sağlamaktadır. İthalat yoluyla öğrenmenin ikinci mekanizması ise, yabancı teknolojilere maruz kalma şeklinde ortaya çıkmaktadır. Bu kapsamda, belirli bir ülke veya bölgede ortaya çıkan teknolojik inovasyonla ilgili öğrenme faaliyetleri, patent araştırmaları, "tersine mühendislik" veya lisanslar yoluyla gerçekleşebilmektedir. Verimlilik artışları genel olarak yerel bilgi stokuna bağlı olduğundan, bu tür öğrenme faaliyetleri yerel bilgi havuzunun gelişimine ve dolayısıyla üretkenliğe katkı sağlayacaktır (Blalock ve Veloso, 2005: 4-5). Dolayısıyla, söz konusu öğrenme etkilerinin genel olarak yüksek bilgi ve teknoloji barındıran malların ortaya çıkardığı teknoloji yayıIımıyla (diffusion) ilişkili olduğu söylenebilir. Bunun yanı sıra, firmaların uluslararası ticaretle birlikte yeni ürünler veya mevcut ürünlerin yeni çeşitlerine ulaşmalarının, üretim süreçlerine konu olan ara girdilerin niteliklerini artırdığı ve bu artışın aynı zamanda verimlilikteki iyileşmelere de katkı sağladığından söz edilebilir (Grossman ve Helpman, 1995: 1312-1316).

Faktör verimliliği kapsamında makroekonomik istikrar ve kurumsal bazı göstergelere ilişkin değişkenlerin ele alındığı farklı çalışmalardan da bahsetmek mümkündür. Bu bağlamda, yakın zaman içerisinde ortaya çıkmış çeşitli çalışmaların (Rodrik vd., 2002; Scarpetta vd., 2002; Acemoglu vd., 2004), gelişmiş kurumların verimlilik ve uzun dönem ekonomik büyüme üzerindeki önemine vurgu yaptığı görülmektedir. Ayrıca, enflasyonun faktör verimlilikteki rolüne ilişkin farklı görüşler de mevcuttur. Bu kapsamda, enflasyonun verimlilik üzerinde bozucu bir etkisinin olduğuna işaret eden sonuçların (Jarret ve Selody, 1982; Smyth, 1995) yanı sıra, bu bozucu etkinin konjonktürel dalgalanmalar sonucu ortaya çıktığı ve dolayısıyla gerçeği yansıtmadığını savunan (Cameron vd., 1996; Freeman ve Yerger, 1998) yaklaşımlar da söz konusudur. 


\section{Literatür İncelemesi}

Toplam faktör verimliliğinin (TFV) belirleyicilerinin analizine yönelik ortaya çıkan ampirik literatürün gelişmiş ülkelerin yanı sıra gelişmekte olan ve az gelişmiş ülkeleri de içerisine aldığı görülmektedir. Tablo 1'de bu çalışmalardan bazıları özetlenmektedir. Bu kapsamda, Coe ve Helpman (1995), 1971-1990 yılları arası dönemde 21 OECD ülkesi ve İsrail kapsamında gerçekleştirdikleri analizde, yurtiçi ve yabancı Ar-Ge sermaye stokunun TFV üzerinde önemli derecede etkili olduğunu bulmuşlardır. Ayrıca çalışma sonucu elde edilen bulgular, ticari dışa açıklığın teknoloji transferi yoluyla TFV'ye katkı sağladığına da işaret etmektedir. Aynı veri setine beşeri sermayeyi de dâhil eden Engelbrecht (1997)'nin çalışmasından elde edilen sonuçlar ise Coe ve Helpman'ın bulgularını desteklerken, beşeri sermayenin TFV'yi pozitif etkilediğini ortaya koymaktadır. Domazlicky ve Weber (1998), ABD'deki 48 Eyalet kapsamında gerçekleştirdikleri çaIışmalarında, özel sektöre ait sermaye birikimindeki artışın TFV üzerinde önemli bir etkisinin olduğunu göstermişlerdir. Ayrıca, imalat sanayindeki büyüme ve metropolitan nüfustaki artışın yığılma ekonomileri yoluyla TFV'yi artırdı̆̆ını bulurken, beşeri sermayeye ilişkin olarak, eğitimin TFV üzerinde anlamlı bir etkisine rastlanmamıştır. 
Ağustos 2017, C. 12, S. 2

Tablo 1. Literatür Özeti

\begin{tabular}{|c|c|c|c|}
\hline Yazar/Lar & Dönem/Veri Seti & Yöntem* & $\begin{array}{c}\text { Değişkenlerin Tfv'ye Etkileri } \\
{\left[(+) \text { : pozitif; }(-) \text { :negatif; }\left({ }^{*}\right) \text { :anlamlı; (/):an- }\right.} \\
\text { lamsız] }\end{array}$ \\
\hline \multicolumn{4}{|c|}{ Ülke/Bölge Düzeyindeki Çalışmalar } \\
\hline $\begin{array}{l}\text { Coe ve Helpman } \\
\text { (1995) }\end{array}$ & 1971-1990 / 21 OECD ülkesi + İsrail & H-EKK & $\begin{array}{l}\text { - Yurtiçi ve yabancı Ar-Ge sermayesi stoku } \\
\left(+^{*}\right)\end{array}$ \\
\hline $\begin{array}{l}\text { Engelbrecht } \\
\text { (1997) }\end{array}$ & 1971-1990 / 21 OECD ülkesi + İsrail & H-EKK & $\begin{array}{l}\text { - Yurtiçi ve yabancı Ar-Ge sermayesi stoku ve } \\
\text { beşeri sermaye }\left(+^{*}\right)\end{array}$ \\
\hline $\begin{array}{l}\text { Domazlicky ve } \\
\text { Weber (1998) }\end{array}$ & 1977-1986 / ABD-48 Eyalet & EKK & $\begin{array}{l}\text { - Özel sektöre ait sermaye birikimi }\left(+^{*}\right) \\
\text { - Beşeri sermaye }(-/)\end{array}$ \\
\hline $\begin{array}{l}\text { Garces Ozanne } \\
(2001)\end{array}$ & $\begin{array}{l}\text { 1973-1990 / Malezya, Singapur, } \\
\text { Güney Kore, Tayvan, Tayland }\end{array}$ & $\begin{array}{l}\text { EKK } \\
\text { Granger Pa- } \\
\text { nel EKK }\end{array}$ & $\begin{array}{l}\text { - Kamu harcamaları, fiyat kontrolleri ve } \\
\text { kamu iktisadi teşebbüsleri }\left(+^{*}\right) \\
\text { - Ticari dışa açıklık }\left(+^{*}\right) \text {, beşeri sermaye }(+/)\end{array}$ \\
\hline $\begin{array}{l}\text { Ascari ve Di } \\
\text { Cosmo (2004) }\end{array}$ & 1985-2000 / İtalya-20 Bölge & $\begin{array}{l}\text { Panel EKK-K } \\
\text { Panel GMY }\end{array}$ & - Ar-Ge harcamaları ve araştırmacı sayısı (+*) \\
\hline Khan (2006) & 1960-2003 / Pakistan & EKK & $\begin{array}{l}\text { - Makroekonomik istikrar, kamu harcama- } \\
\text { ları, DYY ve finansal sektör }\left(+^{*}\right) \\
\text { - Beşeri sermaye (+/), ticari dışa açıklık (-/) }\end{array}$ \\
\hline $\begin{array}{l}\text { Nachega ve Fon- } \\
\text { taine (2006) }\end{array}$ & 1967-2003 / Nijer & Panel EKK & $\begin{array}{l}\text { - Ticari dışa açıklık ve finansal gelişmişlik }\left(+^{*}\right) \\
\text { - Kamu harcamaları }\left(-^{*}\right) \\
\text { - Beşeri sermaye }(+/) \text {, enflasyon (-/) }\end{array}$ \\
\hline Jajri (2007) & 1971-2004 / Malezya & EKK & $\begin{array}{l}\text { - İmalat sanayinde büyüme, çokuluslu şirket- } \\
\text { ler ve ihracat }\left(+^{*}\right) \\
\text { - Kamu yatırımları (-/), beşeri sermaye (+/) }\end{array}$ \\
\hline $\begin{array}{l}\text { Loko ve Diouf } \\
\text { (2009) }\end{array}$ & 1970-2005 / 62 ülke & Panel S-GMY & $\begin{array}{l}\text { - Makroekonomik istikrar, ticari dışa açıklık, } \\
\text { beşeri sermaye, DYY }\left(+^{*}\right) \text {. }\end{array}$ \\
\hline Khan vd. (2010) & 1982-2004 / 16 OECD ülkesi & FM-EKK & $\begin{array}{l}\text { - Ar-Ge ve beşeri sermaye }\left(+^{*}\right) \\
\text { - Ileri teknoloji ürün ithalatı }\left(-^{*}\right) \text {, Illeri tekno- } \\
\text { loji ihracatı }\left(+^{*}\right)\end{array}$ \\
\hline $\begin{array}{l}\text { Arazmuradov vd. } \\
\text { (2013) }\end{array}$ & 1995-2008 / 15 eski Sovyet ülkesi & SSY & - DYY ve beşeri sermaye $\left(+^{*}\right)$ \\
\hline $\begin{array}{l}\text { Gehringer vd. } \\
\text { (2013) }\end{array}$ & 1995-2007 / 17 AB üyesi ülke & AOGT & $\begin{array}{l}\text { - DYY ve ihracat }(+*) \\
\text { - Beşeri sermaye }(+/)\end{array}$ \\
\hline Raggl (2015) & 1980-2009/ 11 MENA ülkesi & $\begin{array}{l}\text { DZ-Panel Sbt. } \\
\text { Etkiler }\end{array}$ & - Beşeri sermaye ve küreselleşme $\left(+^{*}\right)$ \\
\hline $\begin{array}{l}\text { Akinlo ve } \\
\text { Adejumo (2016) }\end{array}$ & 1970-2009 / Nijerya & $\begin{array}{l}\text { HDM } \\
\text { ETF }\end{array}$ & $\begin{array}{l}\text { - Uzun dönemde beşeri sermaye, ticari dışa } \\
\text { açıklık, enflasyon }\left(-^{*}\right) \text {; DYY }\left(+^{*}\right) \\
\text { - Kısa dönemde beşeri sermaye ve ticari dışa } \\
\text { açıklık (+*); DYY ve işsizlik }\left(-^{*}\right)\end{array}$ \\
\hline Filip (2016) & 2000-2013 / 13 Avrupa ülkesi & $\begin{array}{l}\text { Panel EKK } \\
\text { Sbt. Etkiler }\end{array}$ & - Bilgi, teknoloji, altyapı (+*) \\
\hline \multicolumn{4}{|c|}{ Endüstri/Firma Düzeyindeki Çalışmalar } \\
\hline $\begin{array}{l}\text { Biatour vd. } \\
\text { (2011) }\end{array}$ & 1988-2007 / Belçika (21 endüstri) & D-Panel EKK & $\begin{array}{l}\text { - İmalat sanayinde yurtiçi ve yabancı kay- } \\
\text { naklı bilgi taşmaları, Ar-Ge stoku (+*) } \\
\text { - İleri teknoloji endüstrilerde Ar-Ge yatırım- } \\
\text { ları }\left(+^{*}\right)\end{array}$ \\
\hline Tocco (2015) & 1998-2007 / Çin (140.000+ firma) & Panel S-GMY & $\begin{array}{l}\text { - Likidite düzeyi, endüstriyel rekabet, yığın } \\
\text { ekonomileri (+*) } \\
\text { - Ar-Ge harcamaları, ihracat (+/) }\end{array}$ \\
\hline
\end{tabular}

*AOGT: Artırılmış Ortalama Grup tahmincisi; D-Panel EKK: Dinamik EKK; DZ-Panel: Dengesiz Panel; EKK: En Küçük Kareler; EKK-K: EKK Kukla Değişken Modeli; ETF: Etki-Tepki Fonksiyonu; FM-EKK: Fully Modified EKK; HDM: Hata Düzeltme Modeli; H-EKK: Havuzlanmış EKK; S-GMY: Sistem-Genelleştirilmiş Momentler Yöntemi; SSY: Stokastik Sınır Yöntemi. 
Garces Ozanne (2001) tarafından Malezya, Singapur, Güney Kore, Tayvan ve Tayland kapsamında gerçekleştirilen çalışmada kamu harcamaları, fiyat kontrolleri ve kamu iktisadi teşebbüslerinin TFV üzerinde anlamlı birer etkisi olduğu sonucuna ulaşılırken, bu kapsamda yalnızca kamu harcamalarının TFV'ye pozitif etkilediğini bulmuşlardır. Ayrıca, ticari dışa açıklığın TFV üzerindeki etkisi pozitif ancak zayıfken, beşeri sermayenin etkisinin anlamsız olduğunu tespit etmişlerdir. Ascari ve Di Cosmo (2004), İtalya'daki 20 bölge kapsamında gerçekleştirdikleri çaIışma sonucu elde ettikleri bulgular, Ar-Ge harcamaları ve araştırmacıların TFV'yi pozitif ve anlamlı bir şekilde etkilediğini, beşeri sermayenin ise verimlilikte önemli bir belirleyici olduğunu ortaya koymuşlardır. Khan (2006), Pakistan kapsamında 1960-2003 dönemini ele aldığı çalışmasında, makroekonomik istikrar, kamu harcamaları, DYY ve finansal sektörün TFV'yi pozitif yönde etkilediği sonucuna ulaşıımıştır. Çalışmada ayrıca, beşeri sermayenin TFV üzerindeki etkisi pozitif ancak anlamsız, ticari dışa açıklığın ise TFV'ye etkisi negatif ve anlamsız bulunmuştur.

Nachega ve Fontaine'nin (2006) Nijer kapsamında gerçekleştirdikleri çalışmanın bulguları, ticari dışa açıklık ve finansal gelişmişliğin TFV üzerinde önemli birer pozitif etkisi olduğunu gösterirken, kamu harcamalarındaki artışın TFV'yi negatif etkilediğini tespit edilmiştir. Ayrıca, analiz bulgularına göre beşeri sermaye değişkeninin katsayısı pozitif ve enflasyon değişkenin katsayısı ise negatif olmasına karşın, bu katsayılar istatistiksel olarak anlamsız bulunmuşlardır. Malezya genelinde yapılan başka bir çalışmada Jajri (2007), imalat sanayindeki büyüme, çokuluslu şirketlerin varlığı ve ihracatın TFV'yi pozitif yönde etkilediğini ortaya koymuştur. Bunun yanı sıra, çaıışmanın analizinde ele alınan diğer değişkenlerden kamu yatırımları (negatif) ve yükseköğretim mezunlarının istihdam içerisindeki payının (pozitif) TFV üzerindeki etkileri anlamsız bulunmuştur.

Loko ve Diouf (2009) 1970-2005 dönemi için 62 ülkeye ait panel veri seti üzerinde gerçekleştirdikleri analizde, makroekonomik istikrar, ticari dışa açıklık ve beşeri sermayenin (eğitim düzeyi) verimlilikteki artışlarda belirleyici değişkenler oldukları sonucuna ulaşmışlardır. Kurumsal gelişmişliğin TFV üzerinde anlamlı bir etkisinin olduğu ve ayrıca DYY'nin de TFV üzerinde anlamlı ve pozitif bir etki yarattığı da elde edilen diğer bazı sonuçlardandır. Khan vd. (2010) tarafından 16 OECD ülkesi kapsamında gerçekleştirilen çalışma sonucu elde edilen bulgularda ise Ar-Ge ve beşeri sermayenin TFV'de önemli birer belirleyici oldukları sonucuna ulaşılmıştır. Analiz kapsamında ayrıca, ileri teknoloji ithalatının TFV üzerinde etkisi negatif bulunurken, ileri teknoloji ihracatı için bu sonuç pozitiftir. Arazmuradov vd. (2013) tarafından 15 eski Sovyet ülkesi kapsamında gerçekleştirilen başka bir çalışmada, DYY ve beşeri sermayenin TFV üzerinde pozitif etkileri olduğunu tespit etmişlerdir. 17 Avrupa Birliği üyesi ülkeyi içerisine alan bir başka çalışmada Gehringer vd. (2013), DYY ve ihracatın TFV'yi pozitif ve anlamlı bir şekilde etkilediğini ortaya koyarken, beşeri sermayenin TFV'ye etkisinin pozitif ancak anlamsız olduğunu, bilgi ve iletişim teknolojileri kullanımının ise TFV üzerindeki etkisinin görece zayıf olduğunu bulmuşlardır.

Raggl (2015)'in TFV'nin potansiyel belirleyicilerini incelediği çalışma, 1980-2009 dönemi ve Orta Doğu ve Kuzey Afrika (MENA) ülkelerini kapsamaktadır. Çalışmadan elde edilen bulgularda, beşeri sermaye ve küreselleşmenin TFV üzerindeki etkisinin pozitif olduğuna, eğitime katılım oranındaki artışların inovasyon faaliyetlerinin etkinliğine önemli bir katkı sağladığı gözlemlenmiştir. Akinlo ve Adejumo (2016) ise beşeri sermaye, ticari dışa açıklık, DYY, enflasyon ve işsizliğin TFV üzerindeki etkilerini Nijerya kapsamında incelemişlerdir. Yazarlar çalışmada, uzun dönemde beşeri sermaye, ticari dışa açıklık ve enflasyonun TFV üzerindeki etkilerinin negatif, DYY'nin TFV üzerindeki etkisinin ise pozitif olduğunu ortaya koymuşlardır. Bununla birlikte, söz 
konusu değişkenlerin TFV üzerindeki kısa dönem etkilerinin incelendiği analizin ikinci kısmında, beşeri sermaye ve ticari dışa açıklığın TFV üzerinde etkisi pozitif bulunurken, DYY ve işsizliğin etkileri negatif tahmin edilmiştir. 13 Avrupa ülkesi kapsamında gerçekleştirilen başka bir çalışmada Filip (2016), bilgi ve teknoloji, altyapı, eğitim, sağlık hizmetleri ve sermaye kullanım yoğunluğunun TFV üzerindeki etkilerini incelemiştir. Analiz sonucu elde edilen bulgularda bilgi, teknoloji ve altyapıya ilişkin değişkenlerin TFV'deki artışlarda önemli birer rolünün olduğu görülmüştür. Buna karşın, eğitim ve sağlığa ilişkin değişkenlerin TFV üzerindeki etkilerinin görece sınırlı olduğu sonucuna ulaşılmıştır.

Biatour vd. (2011) Belçika üzerine yaptıkları çalışmalarında Ar-Ge faaliyetlerine dayanan bilgi taşmaları, AR-Ge stoku, Ar-Ge yatırımları ve endüstrilere özgü bazı regülasyonların TFV üzerindeki etkilerini endüstri düzeyinde incelemişlerdir. Çalışmadan elde edilen bulgular, yurtiçi ve yabancı kaynaklı bilgi taşmaları ve Ar-Ge stokunun özellikle imalat endüstrilerinin verimliliği üzerinde önemli bir katkısının olduğunu göstermektedir. Ayrıca analizde, Ar-Ge yatırımlarının TFV üzerindeki etkisinin yalnızca ileri teknoloji endüstrilerde pozitif olduğu ve regülasyonlardaki serbestleşmenin ise imalat endüstrileri dışındaki endüstrilerin TFV'si üzerinde negatif etki yarattığı sonucuna ulaşıımıştır. Son olarak, Tocco (2015) tarafından Çin'deki 140 binden fazla firma üzerinde gerçekleştirilen analizin sonuçları ise likidite düzeyi, endüstriyel rekabet, yığın ekonomileri ve endüstriyel çeşitliliğin TFV'yi pozitif etkilediğini göstermiştir. Bunun yanı sıra, piyasaya devlet müdahalesi ile TFV arasında ters yönlü bir ilişkiye rastlanırken, Ar-Ge harcamaları ve ihracatın TFV üzerindeki etkileri anlamsız olarak bulunmuştur.

\section{Veri Seti ve Yöntem}

Çalışmanın analiz kısmına konu olan dengeli panel veri seti, sürekli veri ve uzun dönem zaman serisi kısıtları göz önüne alınarak oluşturulmuştur. Bu kapsamda elde edilen gözlemler 12 OECD ülkesine ( $A B D$, Almanya, Finlandiya, Fransa, Hollanda, Ingiltere, italya, irlanda, ispanya, Japonya, Kanada, Kore) ait 1993-2014 dönemini kapsamaktadır. Analizde bağımlı değişken olarak ele alınan toplam (çoklu) faktör verimliliği endeksi OECD (2017a) veri tabanından elde edilmiştir. TFV endeksi genel olarak, emek ve sermaye girdilerinin birlikte kullanıldığı bir üretim sürecindeki mevcut verimliliğin bütünsel bir ölçütüdür. TFV'deki değişimin, yönetim uygulamaları ve organizasyonel yapıdaki değişimler, ağ etkileri, üretim faktörlerinden kaynaklı bilgi taşmaları, ölçek ekonomileri ve aksak rekabetin etkilerini yansıttığı söylenebilir. TFV'deki büyüme hızı, GSYH'de emek ve sermaye girdilerindeki değişimlerle açıklanamayan artışları temsil eden artık bir terim aracılığıyla ölçülmektedir (OECD, 2017a).

Tablo 2. Değişkenlerin Tanımlanması

\begin{tabular}{|c|c|c|c|}
\hline Değişken & Kısaltma & Gösterge & Kaynak \\
\hline Toplam Faktör Verimliliği & TFV & Çoklu Faktör Verimliliği Endeksi & $\operatorname{OECD}(2017 a)$ \\
\hline Beşeri Sermaye & BES & $\begin{array}{c}\text { Kişi Başına Beşeri Sermaye En- } \\
\text { deksi }\end{array}$ & Feenstra vd. (2015) \\
\hline Ar-Ge Faaliyetleri & ARGE & $\begin{array}{c}\text { Gayri Safi Ar-Ge Harcaması } \\
\text { (\%/GSYH) }\end{array}$ & $\operatorname{OECD}(2017 b)$ \\
\hline Ticari Dışa Açıklık & ACK & [(İhracat + İthalat)/GSYH] & $\operatorname{OECD}(2017 c, 2017 d)$ \\
\hline İleri Teknoloji Ürün İthalatı & ITH & $\begin{array}{c}\text { İşçi Başına İleri Teknoloji Ürün } \\
\text { İthalatı }\end{array}$ & $\begin{array}{c}\text { Birleşmiş Milletler (2017) } \\
\text { Eurostat (2017) } \\
\text { OECD (2017e) }\end{array}$ \\
\hline
\end{tabular}


Analizde kullanılan değişkenlere ait tanımlayıcı bilgiler Tablo 2'de sunulmuştur. TFV'nin belirleyicileri olarak ele alınan değişkenlerden kişi başına beşeri sermaye endeksi Penn World Table 9.0 (Feenstra vd., 2015) veri tabanından, gayri safi Ar-Ge harcaması (GSYH'ye oranı) ve ticari dışa açıklık değişkenleri ise $\operatorname{OECD~(2017b,~2017c,~2017d)~veri~tabanından~elde~edilmiştir.~}$ Son olarak işçi başına düşen ileri teknoloji ürün ithalatı değişkeni ise Birleşmiş Milletler (2017) Comtrade veri tabanından Eurostat (2017) tarafından SITC Rev.3 sınıflamasına göre yayınlanan ileri teknoloji ürün gruplaması referans alınarak tarafımızca elde edilmiş ve işçi başına değerlere OECD (2017e) veri tabanından yararlanılarak dönüştürülmüştür. Ayrıca, değişkenlere ait değişimlerin homojen bir yapıda gözlemlenebilmesi için, OECD tarafından yayınlanan TFV endeksinde temel yıl olarak belirlenen 2010 yılı dikkate alınarak tüm değişkenler söz konusu yıla endekslenerek analize dâhil edilmiştir.

Çalışmada, TFV'nin belirleyicileri panel eş-bütünleşme ve panel nedensellik yöntemleri kullanılarak tahmin edilmiştir. Analizde kullanılan model Eşitlik (1)'de yer alan üretim fonksiyonu aracılığı ile tahmin edilmektedir. Modelde $A R G E, I T H, A C K$ ve BES Tablo 2'de belirtilen açıklayıcı değişkenleri, $\varepsilon$ hata terimini, $i$ ve $t$ alt indisleri ise sırasıyla kesit ve zaman boyutunu göstermektedir.

$T F V_{i t}=\alpha_{0}+\alpha_{1} A R G E_{i t}+\alpha_{2} I T H_{i t}+\alpha_{3} A C K_{i t}+\alpha_{4} B E S_{i t}+\varepsilon_{i t}$

$i=1,2, \ldots, 12$ ve $t=1993, \ldots, 2014$

(1) nolu eşitliğin tahmin edilmesinde ilk olarak, değişkenlerin zaman serisi özellikleri panel birim kök testleri ile analiz edilmektedir. Değişkenlerin birinci dereceden durağan olmaları halinde, panel eşbütünleşme testleri yapılmakta ve FMOLS ve DOLS tahminleri ile eşbütünleşme parametreleri elde edilmektedir. Son olarak ise panel nedensellik testleri ile değişkenler arasındaki nedensellik ilişkileri incelenmektedir.

\section{Bulgular}

Analiz kısmının ilk aşamasında, değişkenlerin durağan olup olmadıklarının tespiti için Breitung (2000), Levin, Lin, Chu (LLC) (2002), Im, Pesaran, Shin (IPS) (2003) testleri ile Maddala ve Wu (1999) ve Choi (2001) tarafından önerilen Fisher-ADF ve Fisher-PP testleri kullanılmıştır. Bu testlerin boş hipotezleri değişkenlerin birim kök içerdiklerini, alternatif hipotez ise değişkenlerin durağan olduklarını ileri sürmektedir. Tablo 3'de panel birim kök test sonuçları rapor edilmiştir. Birim kök sonuçlarına göre TFV değişkeni, LLC testinin sabitli düzeyi hariç, tüm birim kök testlerde hem sabitli hem de sabitli ve trendli düzeyde birim köke sahiptir. ARGE değişkeni LLC, Breitung, IPS, Fisher ADF ve Fisher-PP testlerine göre hem sabitli hem de sabitli ve trendli düzeyde birim köke sahiptir. ACK değişkeni ise, LLC testinin sabitli ve trendli düzeyi hariç, tüm testlerde birim köke sahiptir. ITH değişkeni de sabitli düzeyde IPS, Fisher-ADF ve Fisher-PP, sabitli ve trendli seviyede ise Breitung ve Fisher-PP test istatistiklerinde birim köke sahiptir.

Son olarak BES değişkeni de LLC, Breitung ve IPS testlerinde yüzde beş anlamlılık seviyelerinde birim köke sahiptir. Yapılan testler neticesinde değişkenlerin durağan olduklarını gösteren kesin bir bilgiye ulaşılamamıştır. Bu nedenle serilerin birinci farkı alınarak birinci dereceden durağanlıkları araştırılmıştır. 
Tablo 3. Panel Birim Kök Test Sonuçları

\begin{tabular}{|c|c|c|c|c|c|c|c|c|}
\hline \multicolumn{5}{|c|}{ TFV (Düzey) } & \multicolumn{4}{|c|}{ TFV (Birinci Fark) } \\
\hline & \multicolumn{2}{|c|}{ Sabitli } & \multicolumn{2}{|c|}{ Sabitli ve Trendli } & \multicolumn{2}{|c|}{ Sabitli } & \multicolumn{2}{|c|}{ Sabitli ve Trendli } \\
\hline \multicolumn{9}{|c|}{ Boş Hipotez: Birim Kök (ortak birim kök süreci) } \\
\hline LLC & -3.383 & $(0.000)$ & -0.624 & $(0.266)$ & -7.555 & $(0.000)$ & -7.903 & $(0.000)$ \\
\hline Breitung & & & -0.1949 & $(0.423)$ & & & -4.8162 & $(0.000)$ \\
\hline \multicolumn{9}{|c|}{ Boş Hipotez: Birim Kök (bireysel birim kök süreci) } \\
\hline IPS & -0.4463 & $(0.327)$ & 1.0315 & $(0.849)$ & -7.0362 & $(0.000)$ & -6.3051 & $(0.000)$ \\
\hline ADF-Fisher & 27.2118 & $(0.398)$ & 19.4388 & $(0.817)$ & 98.0294 & $(0.000)$ & 85.0381 & $(0.000)$ \\
\hline PP-Fisher & 41.1699 & $(0.030)$ & 34.4996 & $(0.123)$ & 229.115 & $(0.000)$ & 197.339 & $(0.000)$ \\
\hline \multicolumn{5}{|c|}{ ARGE (Düzey) } & \multicolumn{4}{|c|}{ ARGE (Birinci Fark) } \\
\hline Yöntem & \multicolumn{2}{|c|}{ Sabitli } & \multicolumn{2}{|c|}{ Sabitli ve Trendli } & \multicolumn{2}{|c|}{ Sabitli } & \multicolumn{2}{|c|}{ Sabitli ve Trendli } \\
\hline \multicolumn{9}{|c|}{ Boş Hipotez: Birim Kök (ortak birim kök süreci) } \\
\hline LLC & -0.4053 & $(0.343)$ & 0.1787 & $(0.571)$ & -3.1992 & $(0.001)$ & -2.4464 & 0.0072 \\
\hline Breitung & & & 2.1799 & $(0.985)$ & & & -3.3059 & 0.0005 \\
\hline \multicolumn{9}{|c|}{ Boş Hipotez: Birim Kök (bireysel birim kök süreci) } \\
\hline IPS & 0.8265 & $(0.796)$ & 0.8926 & $(0.814)$ & -3.7506 & $(0.000)$ & -3.0625 & 0.0011 \\
\hline ADF-Fisher & 28.6986 & $(0.325)$ & 26.4693 & $(0.438)$ & 56.6993 & $(0.001)$ & 50.1829 & 0.0030 \\
\hline PP-Fisher & 18.2712 & $(0.866)$ & 15.9445 & $(0.938)$ & 95.0970 & $(0.000)$ & 90.8728 & $(0.000)$ \\
\hline \multicolumn{5}{|c|}{ ACK (Düzey) } & \multicolumn{4}{|c|}{ ACK (Birinci Fark) } \\
\hline Yöntem & \multicolumn{2}{|c|}{ Sabitli } & \multicolumn{2}{|c|}{ Sabitli ve Trendli } & \multicolumn{2}{|c|}{ Sabitli } & \multicolumn{2}{|c|}{ Sabitli ve Trendli } \\
\hline Boş Hipotez: & im Kök (ort & jirim köks & eeci) & & & & & \\
\hline LLC & -1.5984 & $(0.055)$ & -2.5868 & $(0.005)$ & -6.415 & $(0.000)$ & -6.1763 & $(0.000)$ \\
\hline Breitung & & & -0.0063 & $(0.498)$ & & & -5.4687 & $(0.000)$ \\
\hline Boş Hipotez: & im Kök (bir & l birim kö & üreci) & & & & & \\
\hline IPS & -1.0966 & $(0.136)$ & -0.4314 & $(0.333)$ & -6.073 & $(0.000)$ & -4.4856 & $(0.000)$ \\
\hline ADF-Fisher & 31.9504 & $(0.195)$ & 25.1277 & $(0.512)$ & 85.082 & $(0.000)$ & 64.8561 & $(0.000)$ \\
\hline PP-Fisher & 38.1887 & $(0.058)$ & 26.1803 & $(0.453)$ & 142.376 & $(0.000)$ & 136.330 & $(0.000)$ \\
\hline & & (Düzey) & & & & ITH (Bi & Ici Fark) & \\
\hline Yöntem & & & Sabitli & Trendli & & & Sabitli & Trendli \\
\hline Boş Hipotez: & im Kök (ort & birim köks & eci) & & & & & \\
\hline LLC & -2.2199 & $(0.013)$ & -2.5697 & $(0.005)$ & -9.0870 & $(0.000)$ & -7.3146 & $(0.000)$ \\
\hline Breitung & & & -0.9500 & $(0.171)$ & & & -78885 & $(0.000)$ \\
\hline Boş Hipotez: & im Kök (bir & l birim kö & süreci) & & & & & \\
\hline IPS & -0.2285 & $(0.410)$ & -2.5085 & $(0.006)$ & -7.5892 & $(0.000)$ & -5.1852 & $(0.000)$ \\
\hline ADF-Fisher & 23.2743 & $(0.617)$ & 44.1697 & $(0.015)$ & 105.429 & $(0.000)$ & 71.9350 & $(0.000)$ \\
\hline PP-Fisher & 25.9813 & $(0.464)$ & 33.5692 & $(0.146)$ & 192.474 & $(0.000)$ & 163.843 & $(0.000)$ \\
\hline & & (Düzey) & & & & BES (B & 1ci Fark) & \\
\hline Yöntem & & & Sabitli & Trendli & & & Sabitli & Trendli \\
\hline Boş Hipotez: & im Kök (ort & jirim köks & eci) & & & & & \\
\hline LLC & -1.8967 & $(0.029)$ & -1.5931 & $(0.056)$ & -2.0161 & $(0.000)$ & -2.7336 & $(0.003)$ \\
\hline Breitung & & & 2.4858 & (0.994) & & & -2.0359 & $(0.021)$ \\
\hline Boş Hipotez: & im Kök (bir & l birim kö & süreci) & & & & & \\
\hline IPS & -1.7498 & $(0.040)$ & -0.3141 & $(0.377)$ & -4.8644 & $(0.000)$ & -4.6046 & $(0.000)$ \\
\hline ADF-Fisher & 48.3785 & $(0.002)$ & 37.7974 & $(0.036)$ & 87.6197 & $(0.000)$ & 73.3426 & $(0.000)$ \\
\hline PP-Fisher & 98.4061 & $(0.000)$ & 53.6545 & $(0.001)$ & 492.940 & 0.0000 & 421.803 & $(0.000)$ \\
\hline
\end{tabular}


Tablo 3'de değişkenlerin birinci farkları alınarak yapılan test sonuçları da yer almaktadır. Buna göre, değişkenlerin tümünün birinci dereceden durağan oldukları görülmektedir. Başka bir ifadeyle, tahminde kullanılan değişkenlerin tamamı I(1)'dir.

Düzey değerlerinde birim kök bulunan değişkenlerin birinci farkları alındığında birim kök ortadan kalkıyorsa, uzun dönem ilişkisinin araştırılması için eşbütünleşme testleri yapılmalıdır. Değişkenler arasındaki uzun dönemli ilişkilerin olup olmadığını tespit etmek için Pedroni (1999) ve Kao (1999) tarafından geliştirilen panel eşbütünleşme testleri kullanılmıştır.

Tablo 4'de sabit terimli ile sabit terimli ve trendli modelden elde edilen panel eşbütünleşme test sonuçları rapor edilmiştir. Değişkenler arasında eşbütünleşme ilişkisi yoktur boş hipotezi sabit terimli ve trendli modelde Panel rho ve group rho dışındaki istatistikler tarafından reddedilmektedir. Bu sonuçlara göre sabit terimli ve trendli modelde değişkenler arasında uzun dönemde eşbütünleşme ilişkisi bulunmaktadır. Ayrıca Kao kalıntı eşbütünleşme testine göre de yüzde beş düzeyinde boş hipotez reddedildiğinden, uzun dönemde değişkenler arası eşbütünleşme ilişkisinin olduğu görülmektedir.

Tablo 4. Panel Eşbütünleşme Test Sonuçları

\begin{tabular}{lcc}
\hline Kesitler İci Testler (Within Dimension) & & \\
\hline \hline Panel v-istatistiği & Sabit Terimli & Sabit Terimli ve Trendli \\
Panel rho-Istatistiği & -1.6950 & $3.2889^{* * *}$ \\
Panel PP-istatistiği & 2.7224 & 3.3286 \\
Panel ADF-Istatistiği & 1.9818 & $0.3862^{*}$ \\
\hline Kesitlerarası Testler (between-dimension) & 1.7909 & $-1.5718^{*}$ \\
\hline \hline Group rho-Istatistiği & Sabit Terimli & Sabit Terimli ve Trendli \\
Group PP-istatistiği & 3.2482 & 3.7066 \\
Group ADF-istatistiği & -0.3972 & $-2.3092^{* *}$ \\
Kao Kalıntı Eşbütünleşme Testi & $-1.3518^{*}$ & $-1.6716^{* *}$ \\
\hline \hline & & \\
ADF & t-istatistik & \\
Residual variance & $-2.254^{* *}$ & \\
HAC variance & 2.00015 & \\
\hline$* * * *$ ve * sırasıyla yüzde 1, yüzde 5 ve yüzde 10 seviyesindeki anlamlılığı göstermektedir.
\end{tabular}

Modelde eşbütünleşme ilişkisinin tespitinden sonra, panel eşbütünleşme parametreleri belirlenmelidir. Panel DOLS ve Panel FMOLS'den elde edilen eşbütünleşme parametreleri Tablo 5 'de verilmiştir. Buna göre, Panel FMOLS ve panel DOLS tahmincileri ARGE, ITH ve ACK değişkenlerinin TFV'ye etkilerinin yüzde bir anlamlılık düzeyinde istatistiksel olarak anlamlı olduğunu göstermektedir. Dolayısıyla Ar-Ge harcamaları, ileri teknoloji ürün ithalatı ve ticari dışa açıklığın TFV üzerinde pozitif etki yarattıkları söylenebilir. Bununla birlikte, beşeri sermaye değişkenine ait parametre negatif ve istatistiksel olarak anlamsız bulunmuştur. 
Tablo 5. Panel Eşbütünleşme Parametreleri

\begin{tabular}{lcccc}
\hline TFV & ARGE & ITH & ACK & BES \\
\hline \hline Panel FMOLS & $0.1915^{* * *}$ & $0.1107^{* * *}$ & $0.2698 * * *$ & -0.0035 \\
t-stat & {$[4.1476]$} & {$[4.9471]$} & {$[5.1112]$} & {$[-0.3322]$} \\
Panel DOLS & $0.1148^{* *}$ & $0.0761^{* * *}$ & $0.2574 * * *$ & -0.0047 \\
t-stat & {$[2.3741]$} & {$[3.8088]$} & {$[4.2300]$} & {$[-0.3600]$} \\
\hline
\end{tabular}

*** yüzde 1 seviyesindeki anlamlılığı temsil etmektedir.

Tablo 6'da panel Granger nedensellik test sonuçları rapor edilmiştir. Bu sonuçlara göre ITH'den TFV ve ACK'ye doğru Granger Nedensellik ilişkisi yoktur şeklindeki boş hipotez reddedilmektedir. Dolayısıyla iş̧̧i başına ileri teknoloji ürün ithalatından toplam faktör verimliliğine ve ticari dışa açıklığa doğru tek yönlü nedensellik ilişkisi bulunmaktadır. TFV'den ARGE ve BES'e doğru da nedensellik ilişkisi vardır. Başka bir ifadeyle, toplam faktör verimliliğinden ARGE harcamalarına ve beşeri sermayeye doğru Granger nedensellik ilişkisi bulunmaktadır.

Tablo 6: Panel Granger Nedensellik Test Sonuçları

\begin{tabular}{lll}
\hline HO Hipotezi & F-testi & Olasılık \\
\hline \hline ITH TFV'nin Granger Nedenseli Değildir & $\mathbf{4 . 2 1 9 6 1}$ & $\mathbf{0 . 0 1 5 8}$ \\
TFV ITH'nin Granger Nedenseli Değildir & 1.41938 & 0.2439 \\
ARGE TFV'nin Granger Nedenseli Değildir & 0.76601 & 0.4660 \\
TFV ARGE'nin Granger Nedenseli Değildir & $\mathbf{4 . 8 0 5 6 5}$ & $\mathbf{0 . 0 0 9 0}$ \\
ACK TFV'nin Granger Nedenseli Değildir & 1.28769 & 0.2778 \\
TFV ACK'nin Granger Nedenseli Değildir & 0.64310 & 0.5266 \\
BES TFV'nin Granger Nedenseli Değildir & 0.15561 & 0.8560 \\
TFV BES'nin Granger Nedenseli Değildir & $\mathbf{4 . 7 3 5 5 2}$ & $\mathbf{0 . 0 0 9 6}$ \\
ARGE ITH'nin Granger Nedenseli Değildir & 1.17868 & 0.3095 \\
ITH ARGE'nin Granger Nedenseli Değildir & 1.47432 & 0.2310 \\
ACK ITH'nin Granger Nedenseli Değildir & 1.90995 & 0.1504 \\
ITH ACK'nin Granger Nedenseli Değildir & $\mathbf{3 . 0 2 7 9 0}$ & $\mathbf{0 . 0 5 0 3}$ \\
BES ITH'nin Granger Nedenseli Değildir & $\mathbf{3 . 4 8 5 2 5}$ & $\mathbf{0 . 0 3 2 2}$ \\
ITH BES'nin Granger Nedenseli Değildir & 0.70071 & 0.4973 \\
ACK ARGE'nin Granger Nedenseli Değildir & $\mathbf{3 . 9 6 3 4 5}$ & $\mathbf{0 . 0 2 0 3}$ \\
ARGE ACK'nin Granger Nedenseli Değildir & 1.23172 & 0.2937 \\
BES ARGE'nin Granger Nedenseli Değildir & 2.09054 & 0.1259 \\
ARGE BES'nin Granger Nedenseli Değildir & 1.05168 & 0.3510 \\
BES ACK'nin Granger Nedenseli Değildir & 1.06329 & 0.3470 \\
ACK BES'nin Granger Nedenseli Değildir & $\mathbf{4 . 0 8 9 5 3}$ & $\mathbf{0 . 0 1 8 0}$ \\
\hline
\end{tabular}

Yine Tablo 6'daki sonuçlar doğrultusunda BES'den ITH'ye ve ACK'den ARGE ve BES'e doğru da Granger nedensellik ilişkisi tespit edilmiştir. Bunun yanı sıra, beşeri sermayenin işçi başına ileri teknoloji ürün ithalatının ve ticari dışa açıklığın ise Ar-Ge harcamaları ve beşeri sermayenin Granger nedenseli olduğu görülmektedir. 


\section{Sonuç ve Değerlendirme}

Bu çalışmada toplam faktör verimliliğinin belirleyicileri ampirik olarak analiz edilmiştir. Bu bağlamda Ar-Ge harcamaları, ileri teknoloji ürün ithalatı, ticari dışa açıklık ve beşeri sermayenin toplam faktör verimliliği üzerindeki etkileri 12 OECD ülkesi kapsamında 1993-2014 dönemi için tahmin edilmiştir. Analizlerde kullanılan değişkenlerin düzeyde birim kök içerdikleri tespit edilmiştir. Bu değişkenlerin uzun dönemde eşbütünleşik oldukları kesit içi testleri Panel-PP ve Panel ADF; kesitlerarası testlerden de Group-PP ve Group-ADF test istatistikleri ile doğrulanmıştır.

Panel DOLS ve Panel FMOLS'den elde edilen eşbütünleşme parametreleri (i) arge harcamaları, (ii) ileri teknoloji ürün ithalatı ve (iii) ticari dışa açıklık değişkenlerinin TFV'yi pozitif ve istatistiksel olarak anlamlı bir şekilde etkilediğini göstermektedir. Bununla birlikte, beşeri sermaye değişkenine ait katsayı negatif ve istatistiksel olarak anlamsız bulunmuştur. Analizde kullanılan beşeri sermaye endeksinin temel olarak eğitimde geçirilen ortalama süre dikkate alınarak hesaplandığı düşünüldüğünde, ortaya çıkan bu sonucun literatürdeki benzer çalışmaların (Domazlicky ve Weber, 1998; Garces Ozanne, 2001; Khan, 2006; Nachega ve Fontaine, 2006; Jajri, 2007; Gehringer vd., 2013) sonuçlarıyla örtüştügü görülmektedir. Dolayısıyla beşeri sermayenin ölçümünde yalnızca eğitimde geçirilen süreyi dikkate alan bir yaklaşımın, eğitimin niteliğinde ortaya çıkabilen farklılıkları tam anlamıyla yansıtamadığını söylemek mümkündür.

Analiz sonucu elde edilen bulgular, TFV'deki artışlarda Ar-Ge faaliyetlerinin önemli bir rolünün olduğunu ortaya koyan diğer çalışmaları (Coe ve Helpman, 1995; Engelbrecht, 1997; Ascari ve Di Cosmo, 2004; Khan vd., 2010) büyük ölçüde desteklemektedir. Bu bağlamda, başta bilgi stoku olmak üzere uzmanlık ve yaratıcılık gibi Ar-Ge girdilerine kaynak sağlayan harcamaların, katma değeri yüksek bilgi ve teknolojilerin ortaya çıkışını hızlandırarak verimlilik artışlarına katkı sağladığı söylenebilir. Benzer şekilde, ticari dışa açıklığın verimlilik artışındaki pozitif etkisine dair elde edilen bulgunun diğer çalışmaların (Garces Ozanne, 2001; Nachega ve Fontaine, 2006; Loko ve Diouf, 2009) sonuçlarıyla örtüşür olduğu görülmektedir. Dolayısıyla, uluslararası ticarete yönelik faaliyet hacmindeki artışla birlikte ortaya çıkan dışsallıklar ve bazı rekabetçi baskıların, bilgi taşmaları yoluyla firmaların verimliliklerine önemli bir katkı sağladığından bahsedilebilir. Son olarak, çalışmada ele alınan ileri teknoloji ürün ithalatının TFV'ye ilişkin ampirik literatüre pek fazla konu edilmediği görülmektedir. Analiz kısmından elde edilen sonuçlar, Khan vd. (2010) tarafından OECD ülkeleri kapsamında elde edilen sonuçlardan farklı olarak, ileri teknoloji ithalatının TFV üzerinde önemli bir rol oynadığına işaret etmektedir. Bu bağlamda ileri teknoloji ürün ithalatının, yeni teknolojiler ve Ar-Ge faaliyetlerinin somutlaşmış bir hali olan ürünler veya ara girdiler aracılığıyla verimlilik artışlarına anlamlı bir katkı sağladığını ifade etmek mümkündür. Analiz kısmında, işçi başına ileri teknoloji ürün ithalatından toplam faktör verimliliğine doğru tek yönlü olarak bulunan nedensellik ilişkisi de söz konusu katkıyı destekler niteliktedir. Nedensellik analizinden elde edilen diğer bulgularda, işçi başına ileri teknoloji ürün ithalatından ticari dışa açıklığa doğru ve toplam faktör verimliliğinden Ar-Ge harcamalarına ve beşeri sermayeye doğru tek yönlü Granger nedensellik ilişkisinin varlığına ulaşılmıştır. Ayrıca, beşeri sermayenin iş̧̧i başına ileri teknoloji ürün ithalatının ve ticari dışa açıklığın da Ar-GE harcamalarının ve beşeri sermayenin Granger nedenseli olduğu görülmektedir.

Sonuç olarak, başta Ar-Ge faaliyetlerinin finansmanı olmak üzere dış ticaret hacmindeki artış ve ileri teknoloji ediniminin, yeni bilgi üretimi ve pozitif dışsallıklar yoluyla uzun dönem verimlilik artışlarına önemli katkılar sağladığı ifade edilebilir. Dolayısıyla, verimlilik odaklı politikalar bağlamında söz konusu unsurların geliştirilmesine öncelik verilmesi, bu politikalardan elde edilecek çıktıların etkinliğini artırabilecektir. 


\section{Kaynaklar}

Abramovitz, M. (1956), Resource and Output Trends in the United States Since 1870, New York: National Bureau of Economic Research.

Acemoglu, D., S. Johnson ve J. Robinson (2004), "Institutions as the Fundamental Cause of Long-Run Growth", http://www.nber.org/papers/w10481, (Erişim: 26.02.2017).

Aghion, P. ve P. Howitt (1998), Endogenous Growth Theory, Cambridge: MIT Press.

Aghion, P. ve P. Howitt (2009), The Economics of Growth, Cambridge: MIT Press.

Akınlo, A. E. ve O. O. Adejumo (2016), “Determinants of Total Factor Productivity Growth in Nigeria, 1970-2009”, Global Business Review, Vol. 17 No.2: 257-270.

Arazmuradov, A., G. Martini ve D. Scotti (2013), “Determinants of total factor productivity in former Soviet Union economies: A stochastic frontier approach", Economic Systems, Vol. 38 No. 2014: 115-135.

Arrow, K. (1962), "The economic implications of learning by doing", Rev. Econ. Studies, Vol. 29: 155-173.

Ascari, G. ve V. Di Cosmo (2004), "Determination of Total Factor Productivity in Italian Regions", https://www.econstor.eu/bitstream/10419/87139/1/495746169. pdf, (Erişim: 17.02.2017).

Barro, R. J. ve J. W. Lee (1993), "International Comparisons of Educational Attainment", Journal of Monetary Economics, Vol. 32: 363-394.

Benhabib, J. ve M. M. Spiegel (1994), "The Role of Human Capital in Economic Development: Evidence From Aggregate Cross-Country Data", Journal of Monetary Economics, Vol. 34: 143-173.

Biatour, B. (2011), " The determinants of industry-level total factor productivity in Belgium", http://www.plan.be/admin/uploaded/201105200836310.wp201107. pdf, (Erişim: 17.02.2017).

Birleşmiş Milletler (2017), UN Comtrade: International Trade Statistics Database", https://comtrade.un.org/data/, (Erişim: 11.02.2017).

Blalock, G. ve F. Veloso (2005), "Trade, Technology Transfer and Productivity Growth: The Neglected Role of Imports", http://blalock.dyson.cornell.edu/wp/imports_062305.pdf, (Erişim: 17.02.2017).

Breitung, J. (2000), "The Local power of some unit root test for panel data: nonstationary panels, panel cointegration and dynamic panels", Advences in Econometrics, Vol. 15: 161-177.

Cameron, N., D. Hum ve W. Simpson (1996), "Stylized Facts and Stylized Illusions: Inflation and Productivity Revisited" Canadian Journal of Economics, Vol. 24: 152-162.

Canton, E. (2007), "Social Returns to Education: Macro-Evidence", De Economist, Vol. 155 No. 4: 449-468.

Choi, I. (2001), "Unit root tests for panel data", Journal of International Money and Finance, Vol. 20 No. 2: $249-272$.

Coe, D. ve E. Helpman (1995), “International R\&D spillovers", European Economic Review, Vol. 39: 859-887.

Denison, E. F. (1969), "Some Major Issues in Productivity Analysis: An Examination of Estimates by Jorgenson and Griliches", Survey of Current Business, Vol. 49: 1-28.

Domazlicky, B. R. ve W. L. Weber (1998), “Determinants of Total Factor Productivity, Technological Change, and Efficiency Differentials Among States, 1977-86", Review of Regional Studies, Vol. 28 No. 2: 19-33.

Dünya Bankası (2000), “Measuring growth in total factor productivity”, www1.worldbank.org/prem/PREMNotes/premnote42.pdf, (Erişim:21.02.2017).

Easterly, W. ve R. Levine (2001), "It's Not Factor Accumulation: Stylized Facts and Growth Models", The World Bank Economic Review, Vol. 15 No. 2: 177-219.

Edwards, S. (1998), “Openness, Productivity and Growth: What Do We Really Know?”, The Economic Journal, Vol. 108: 383-398.

Engelbrecht, H-J. (1997), “International R\&D Spillovers, Human Capital and Productivity in OECD Economies: An Empirical Investigation”, European Economic Review, Vol. 41: 1479-1488.

Eurostat (2017), "High-tech aggregation by SITC Rev.3", http://ec.europa.eu/eurostat/cache/metadata/Annexes/htec_esms_an4.pdf, (Erişim: 10.02.2017).

Feenstra, R. C., R. Inklaar ve M. P. Timmer (2015), "The Next Generation of the Penn World Table", American Economic Review, Vol. 105 No. 10: 3150-3182.

Filip, B. F. (2016), “Total Factor Productivity Determinants in Developed European Countries”, Journal of Public Administration, Finance and Law, Vol. 10 No. 2016: 123-131. 


\section{Eskişehir Osmangazi Üniversitesi iiBF Dergisi}

Freeman, D. G. ve D. Yerger (1998), “Inflation and multifactor productivity growth: A response to Smyth", Applied Economics Letters, Vol. 5 No. 5: 271-274.

Garces-Ozanne, A. L. (2001), " The Determinants of Total Factor Productivity: The High-Performing Asian Economies Revisited", https://ourarchive.otago.ac.nz/ bitstream/handle/10523/1475/PhD_thesis.pdf, (Erişim: 22.02.2017).

Gehringer, A., I. Martinez-Zarzoso ve F. N.-L. Danziger (2013), "The Determinants of Total Factor Productivity in the EU: Insights from Sectoral Data and Common Dynamic Processes", http://ecomod.net/system/files/EcoMod_submission.pdf, (Erişim: 23.02.2017).

Grossman, G. ve E. Helpman (1995), "Technology and Trade”, Handbook of International Economics (Vol. 3), (Ed. Gene Grossman ve Kenneth Rogoff), Amsterdam: Elsevier Science: 1279-1337.

Guellec, D. ve B. van Pottelsberghe (2001), "R\&D and Productivity Growth: Panel Data Analysis of 16 OECD Countries", https://www.oecd.org/eco/growth/1958639.pdf, (Erişim: 11.02.2017).

Hall, R. E. ve C. Jones (1999), "Why Do Some Countries Produce So Much More Output per Worker than Others?", Quarterly Journal of Economics, Vol. 114 No. 1: 83-116.

Im, K. S., M. H. Pesaran ve Y. Shin (2003), "Testing for unit roots in heterogeneous panels", Journal of Econometrics, Vol. 115: 53-74.

Isaksson, A. (2007), "Determinants of total factor productivity:a literature review", http://www.unido.org//fileadmin/user_media/Publications/Research_ and_statistics/Branch_publications/Research_and_Policy/Files/Working_Papers/2007/WP022007\%20-\%20Determinants\%20of\%20total\%20factor\%20productivity.pdf, (Erişim: 15.02.2017).

Jajri, I. (2007), "Determinants of Total Factor Productivity Growth in Malaysia", Journal of Economic Cooperation, Vol. 28 No. 3: 41-58.

Jarrett, J. P., ve J. G. Selody (1982), "The Productivity-Inflation Nexus in Canada”, The Review of Economics and Statistics, Vol. 64 No. 3: 361-367.

Jorgenson, D. W. ve Z. Griliches (1967), "The explanation of productivity change", The Review of Economic Studies, Vol. 34 No. 3: 249-283.

Kao, C. (1999), "Spurious regression and residual-based tests for cointegration in panel data", Journal of Econometrics, Vol. 90: 1-44.

Khan, M., K. B Luintel ve K. Theodoridis (2010), "How Robust is the R\&D -Productivity Relationship? Evidence from OECD Countries", http://www.wipo.int/edocs/pubdocs/en/wipo_pub_econstat_wp_1.pdf, (Erişim: 20.02.2017).

Khan, S. U. (2006), "Macro Determinants of Total Factor Productivity in Pakistan”, SBP Research Bulletin, Vol. 2 No. 2: 383-401.

Levin, A., C.-F. Lin ve C.-S. Chu (2002), "Unit root tests in panel data: Asymptotic and finite-sample properties", Journal of Econometrics, Vol. 108: 1-24.

Loko, B. ve M. A. Diouf (2009), “Revisiting the Determinants of Productivity Growth: What's new?", https://www.imf.org/external/pubs/ft/wp/2009/wp09225.pdf, (Erişim: 21.02.2017).

Maddala, G. S. ve S. Wu (1999), "A comparative study of unit root tests with panel data and a new simple test", Oxford Bulletin of Economics and Statistics, Vol. 61: 631-652.

Miller, S. M. ve M. P. Upadhyay (2000), "The effects of openness, trade orientation, and human capital on total factor productivity", Journal of Development Economics, Vol. 63 No. 2: 399-423.

Nachega, J.-C. ve T. Fontaine (2006), "Economic Growth and Total Factor Productivity in Niger", https://www.imf.org/external/pubs/ft/wp/2006/wp06208.pdf, (Erişim: 18.02.2017).

Nelson, R. ve E. Phelps (1966) "Investment in humans, technological diffusion, and economic growth", American Economic Review, Vol. 56 No. 1/2: 69-75.

OECD (1993), The Measurement of Scientific and Technological Activities: Standard Practice for Surveys of Research and Experimental Development - Frascati Manual 1993, Paris: Organisation for Economic Cooperation and Development.

OECD (2001), "Measuring Productivity: Measurement of Aggregate and Industry-Level Productivity Growth", https://www.oecd.org/std/productivity-stats/2352458.pdf, (Erişim: 17.01.2017).

OECD (2001), The Well-being of Nations: The Role of Human and Social Capital, Paris: Organisation for Economic Cooperation and Development. 
OECD (2004), The Sources of Economic Growth in OECD Countries, Paris: Organisation for Economic Co-operation and Development.

OECD (2015), "OECD Compendium of Productivity Indicators 2015", http://www.oecd-ilibrary.org/industry-and-services/oecd-compendium-of-productivity-indicators-2015_pdtvy-2015-en, (Erişim: 11.02.2017).

OECD (2017a), "Growth in GDP per capita, productivity and ULC: Multifactor productivity", http://stats.oecd.org//ndex.aspx?DataSetCode=PDB_GR, (Erişim: 13.02.2017).

OECD (2017b), "Gross domestic spending on R\&D (indicator)", https://data.oecd.org/rd/gross-domestic-spending-onr-d.htm, (Erişim: 15.02.2017).

OECD (2017c), "Trade in goods and services (indicator)" https://data.oecd.org/trade/trade-in-goods-and-services.htm, (Erişim: 13.02.2017).

OECD (2017d), "Gross domestic product (GDP) (indicator)", https://data.oecd.org/gdp/gross-domestic-productgdp.htm, (Erişim: 13.02.2017).

OECD (2017e), "LFS by sex and age" http://stats.oecd.org/Index.aspx? DataSetCode=LFS_D, (Erişim: 13.02.2017).

Parham, D. (2007), "Empirical analysis of the effects of R\&D on productivity: Implications for productivity measurement?", https://www.oecd.org/std/ productivity-stats/37511005.pdf, (Erişim: 17.02.2017).

Pedroni, P. (1999), "Critical values for cointegration tests in heterogeneous panels with multiple regressors", Oxford Bulletin of Economics and Statistics, Vol. 61: 653-670.

Raggl, A. K. (2015), "Determinants of Total Factor Productivity in the Middle East and North Africa", Rev. Middle East Econ. Fin., Vol. 11 No. 2: 119-143.

Rodrik, D., A. Subramanian ve F. Trebbi (2002), “Institutions Rule: The Primary of Institutions over Geography and Integration in Economic Development", http://www.nber.org/papers/w9305.pdf, (Erişim: 24.02.2017).

Romer, P. (1990), “Endogenous Technical Change”, Journal of Political Economy, Vol. 98: 71-102.

Scarpetta, S., P. Hemmings, T. Tressel ve J. Woo (2002), "The Role of Policy and Institutions for Productivity and Firm Dynamics: Evidence from Micro and Industry Data", http://www.oecd-ilibrary.org/docserver/download/547061627526. pdf?expires $=1494981316 \& i d=i d \&$ accname=guest\&checksum =3C37BA5BFB991CADFBAC55B0557D61FF, (Erişim: 14.02.2017).

Smyth, D. J. (1995), "The supply side effect of inflation in the United States: Evidence from multifactor productivity", Applied Economics Letters, Vol. 2 No. 12: 482-483.

Solow, R. M. (1956), "A Contribution to the Theory of Economic Growth", The Quarterly Journal of Economics, Vol. 70 No. 1: 65-94.

Solow, R. M. (1957), "Technical Change and the Aggregate Production Function", Review of Economics and Statistics, Vol. 39 No. 3: 312-320.

Stigler, G. J. (1947), Trends in Output and Employment, New York: National Bureau of Economic Research.

The Congress of the United States (2005), "R\&D and Productivity Growth", https://www.cbo.gov/sites/default/files/cbofiles/ftpdocs/64xx/doc6482/06-17-r-d.pdf, (Erişim: 11.02.2017).

Tocco, C. (2015), "An Analysis of the Determinants of Total Factor Productivity in China", http://etheses.dur.ac.uk/11361/, (Erişim: 10.02.2017). 
Eskişehir Osmangazi Üniversitesi iiBF Dergisi 